\title{
PENERAPAN DIET BEBAS GLUTEN BEBAS KASEIN PADA ANAK AUTIS
}

\author{
Ella Oktarina, Jumiyati, Desri Suryani \\ Politeknik Kesehatan Kementerian Kesehatan Bengkulu, Jurusan Gizi, \\ Jalan Indragiri Nomor 03 Padang Harapan Bengkulu \\ jmkbengkulu@gmail.com
}

\begin{abstract}
Gluten-free diet and casein one form of therapy that aims to improve the metabolism of the body with a certain intake of children consumed autism. Gluten and casein in children are not allowed because of increased bowel permeability. The purpose of this research is to know the relationship of nutritional knowledge and maternal obedience in applying a casein-free gluten free diet in autistic children in Bengkulu City. The research design used was observational with Cross sectional study approach. The sample of this research is all mothers who have children who have autism in Bengkulu City as much as 42 respondents, sampling technique in total sampling. This study is from January to February 2016. Data analysis using chi-square. There was no correlation between nutritional knowledge and maternal obedience in applying a caseinfree gluten-free diet in autistic children in Bengkulu City $(\mathrm{p}=0,534$.) It is recommended that parents pay attention to nutritional adequacy of the respondents and abstinence ie food sources of gluten and casein.
\end{abstract}

Keywords : autism, mothers of children with autism, nutritional knowledge, maternal obedience

\begin{abstract}
Abstrak : Diet bebas gluten dan kasein salah satu bentuk terapi yang bertujuan untuk memperbaiki metabolisme tubuh dengan asupan tertentu yang dikonsumsi anak autisme. Gluten dan kasein pada anak tidak diperbolehkan karena terjadi peningkatan permeabilitas usus. Tujuan penelitian ini adalah mengetahui hubungan pengetahuan gizi dan kepatuhan ibu dalam menerapkan diet bebas gluten bebas kasein pada anak autis di Kota Bengkulu. Desain penelitian yang digunakan adalah observasional dengan pendekatan study Cross sectional. Sampel penelitian ini adalah seluruh ibu yang mempunyai anak yang menyandang autis di Kota Bengkulu sebanyak 42 responden, teknik pengambilan sampel secara Total sampling. Penelitian ini selama bulan Januari-Februari 2016. Analisis data menggunakan chi-square. Hasil tidak terdapat hubungan pengetahuan gizi dengan kepatuhan ibu dalam menerapkan diet bebas gluten bebas kasein pada anak autis di Kota Bengkulu $(p=0,534$.) Disarankan agar orang tua untuk memperhatikan kecukupan gizi pada responden dan pantangan yaitu sumber makanan dari gluten dan kasein.
\end{abstract}

Kata Kunci : autisme, ibu anak menyandang autis, pengetahuan gizi, kepatuhan ibu

Autisme merupakan suatu ganguan perkembangan yang kompleks yang menyangkut komunikasi, interaksi sosial dan aktivitas imajinasi. Adanya gangguan pada setiap tahap akan menyebabkan hambatan pada tahap selanjutnya, sehingga deteksi dini, monitor dan stimulasi pertumbuhan dan perkembangan serta intervensi dini merupakan upaya penting untuk mengoptimalkan pertumbuhan dan perkembangan (Dewanti, 2014).
Autisme dapat terjadi pada siapa saja, tidak mengenal asal etnis, bangsa, keadaan sosial ekonomi, dan keadaan intelektualitas orang tua. (Winarno, dkk 2009).

Makanan merupakan suatu hal yang juga harus diperhatikan pada anak dengan gangguan autisme. Makanan yang tampak begitu lezat dan menggoda ternyata tidaklah sebaik penampilannya bila diberikan kepada anak dengan autis pun menjadi sangat terbatas (Winarno, 2009). 
Diet bebas gluten dan kasein adalah salah satu bentuk terapi yang bertujuan untuk memperbaiki metabolisme tubuh dengan asupan tertentu yang dikonsumsi anak (Sunu,2012).

Gluten dan kasein pada anak tidak diperbolehkan karena terjadi peningkatan permeabilitas usus (leaky gut) sehingga memungkinkan peptide dari kasein dan gluten yang tidak tercerna keluar dari dinding usus masuk ke aliran darah. Selain itu,adanya gangguan enzim Dipeptidylpept idase IV mengakibatkan gluten dan kasein tidak tercerna dengan sempurna (CDC, 2008).

Orang tua merupakan sumber saran praktis yang berharga (Sastry dan Aguirre, 2012). Peran orang tua sangat lah penting untuk anak autis, orang tua merupakan salah satu faktor yang sangat berpengaruh terhadap penerapan diet bebas gluten bebas kasein pada anak autisme, karena pola makan pada anak autisme tidak terlepas dari peran seorang ibu dalam menyediakan makanan yang baik serta bergizi dan sesuai dengan kebutuhannya (Sofia, A.D., Ropi,H, dan Mardhiyah. 2013).

Hasil penelitian sebelumnya yang dilakukan oleh Sofia menyebutkan bahwa sebagian kecil (15\%) orang tua yang patuh dalam menerapkan diet bebas gluten dan kasein (BGBK) dan (85\%) orang tua yang tidak patuh dalam menerapkan diet bebas gluten dan kasein (BGBK). Hal tersebut mununjukkan bahwa masih banyak orang tua yang belum atau tidak menerapkan diet bebas gluten bebas kasein (BGBK) sesuai dengan aturannya, karena mereka tidak menghilangkan seluruh sumber makanan atau minuman yang mengandung kasein dan gluten dalam menu makan anaknya.

Pengetahuan yang baik mempunyai tingkatan mengetahui, memahami, mengaplikasikan, menganalisis, mensintetis, dan mengevaluasi (Notoadmodjo, 2010). Pengetahuan ibu tentang autis inilah yang menentukan keputusan orang tua untuk bersikap dan selanjutnya turut ber- partisipasi dalam penanganan anak autis dirumah.

\section{BAHAN DAN CARA KERJA}

Jenis penelitian ini adalah penelitian observasional dengan desain Cross sectional. Populasi dalam penelitian adalah ibu yang mempunyai anak menyandang autis di Kota Bengkulu Tahun 2016. Sampel berjumlah 42 orang yang diambil secara Total sampling.

\section{HASIL}

\section{Analisis Univariat}

Analisis Univariat yaitu berupa distribusi pengetahuan gizi ibu dan kepatuhan ibu dalam menerapkan diet bebas gluten bebas kasein pada anak autis di Kota Bengkulu Tahun 2016.

Tabel 1. Distribusi Frekuesi Tingkat Pengetahuan Ibu dan Kepatuhan Ibu Dalam Menerapkan Diet Bebas Gluten Bebas Kasein pada Anak Autis

\begin{tabular}{lll}
\hline Variabel & $\mathbf{n}$ & $\mathbf{\%}$ \\
\hline Tingkat pengetahuan gizi & & \\
$\quad$ Tidak baik & 8 & 19 \\
$\quad$ Baik & 34 & 81 \\
Total & $\mathbf{4 2}$ & $\mathbf{1 0 0}$ \\
Kepatuhan ibu & & \\
$\quad$ Tidak patuh & 12 & 28.6 \\
$\quad$ Patuh & 30 & 71.4 \\
Total & $\mathbf{4 2}$ & $\mathbf{1 0 0}$ \\
\hline
\end{tabular}

Tabel 1 dapat dilihat bahwa tingkat pengetahuan gizi ibu sebagian besar baik yaitu sebanyak 34 orang $(81 \%)$ dan pengetahuan gizi ibu yang tidak baik hanya 8 orang (19\%). Dapat dilihat bahwa tingkat kepatuhan ibu dalam menerapkan diet bebas gluten bebas kasein sebagian besar patuh yaitu sebanyak 30 orang $(71.4 \%)$ dan kepatuhan ibu yang tidak patuh hanya 12 orang $(28.6 \%)$.

\section{Analisa Bivariat}

Untuk bivariat digunakan untuk mengetahui hubungan antara pengetahuan gizi dengan kepatuhan ibu dalam menerapkan bebas gluten bebas kasein pada anak autisme di Sekolah Pendidikan Khusus dan 
Pendidikan Layananan Khusus Mutiara Bunda Kota Bengkulu, RS. Jiwa Soeprapto, Autis Center. Analisis data menggunakan uji chi-square dengan tingkat kepercayaan $95 \%$.

Tabel 2 Hubungan Tingkat pengetahuan Gizi dengan Kepatuhan Ibu dalam Menerapkan Diet Bebas Gluten Bebas Kasein pada Anak Autis di Kota Bengkulu

\begin{tabular}{|c|c|c|c|c|c|c|c|}
\hline \multirow{3}{*}{$\begin{array}{c}\text { Tingkat Penge- } \\
\text { tahuan Ibu }\end{array}$} & \multicolumn{4}{|c|}{ Kepatuhan } & \multirow{2}{*}{\multicolumn{2}{|c|}{ Total }} & \multirow{3}{*}{ p value } \\
\hline & \multicolumn{2}{|c|}{ Tidak Patuh } & \multicolumn{2}{|c|}{ Patuh } & & & \\
\hline & $\mathbf{n}$ & $\%$ & $\mathbf{N}$ & $\%$ & $\mathbf{n}$ & $\%$ & \\
\hline Baik & 9 & 26.5 & 25 & 73.5 & 34 & 100 & 0,534 \\
\hline Total & 12 & 64 & 30 & 136 & 42 & 100 & \\
\hline
\end{tabular}

Tabel 2 menunjukkan bahwa dari 8 ibu dengan pengetahuan tidak baik, terdapat 3 orang ibu $(37,5 \%)$ tidak patuh dalam menerapkan diet. Sedangkan dari 34 ibu yang memiliki tingkat pengetahuan baik, terdapat 25 orang ibu patuh dalam menerapkan diet $(73.5 \%)$.

Hasil uji statistik menggunakan chi square diperoleh nilai $\mathrm{p}=0,534(>0,05)$ ini menunjukkan tidak ada hubungan antara tingkat pengetahuan dengan kepatuhan ibu.

\section{PEMBAHASAN}

Hubungan Pengetahuan Gizi dengan Kepatuhan Ibu dalam Menerapkan Diet Bebas Gluten Bebas Kasein pada Anak Autis

Hasil penelitian menunjukkan tidak ada hubungan antara pengetahuan gizi ibu dengan tingkat kepatuhan ibu dalam menerapkan diet bebas gluten bebas kasein pada anak autis di Kota Bengkulu Tahun 2016. Penelitian ini sejalan dengan penelitian Farlina (2015) yang mengemukakan tidak ada hubungan antara pengetahuan gizi dengan kepatuhan ibu.

Pengetahuan ini terjadi setelah seseorang melakukan penginderaan terhadap suatu objek tertentu. Sebagian besar pengetahuan manusia diperoleh melalui mata dan telinga. Pengetahuan merupakan domain yang sangat penting untuk terbentuknya perilaku seseorang.

Responden yang berpengetahuan gizi baik dan patuh mengetahui banyak hal tentang diet pada anak autis, dilihat dari pertanyaan yang mampu dijawab pada saat penelitian, hampir semua di jawab benar kecuali ada beberapa indikator mengenai anak autis tidak dapat menyerap nutrisi dari usus karena mengalami kebocoran dinding usus (leaky gut syndrome) dan salah sau jenis makanan yang tidak dianjurkan anak autis tidak tepat dalam menjawabnya.

Tidak adanya hubungan yang signifikan antara hubungan pengetahuan gizi dengan kepatuhan ibu dalam menerapkan diet bebas gluten bebas kasein pada anak autis, Menurut peneliti kemungkinan disebabkan karena ibu tidak tega dalam menerapkan diet pada anak autis sehingga ibu memberikan jika permintaannya terhadap makanan tidak terpenuhi walaupun ibu sangat mengetahui pantangan makanan bagi anak autis. sedangkan dari hasil kuesioner pengetahuan gizi dan kepatuhan ibu baik karena responden dapat menjawab benar setiap pertanyaan yang ada di kuesioner. Kurangnya kemampuan ibu untuk mengendalikan keinginan pada anak autis untuk patuh dalam menerapkan diet bebas gluten bebas kasein pada anak autis. Kepatuhan berkenaan dengan kemauan dan kemampuan indvidu untuk mengikuti cara sehat yang berkaitan dengan nasihat, aturan yang ditetapkan, mengikuti jadwal.

Meskipun pengetahuan merupakan salah satu faktor yang di duga dapat mempengaruhi kepatuhan ibu dalam menerpakan diet. Hal ini sejalan dengan teori model keyakinan kesehatan dimana prilaku kesehatan akan tumbuh dari keinginan individu untuk menghindari suatu penyakit dan kepercayaan bahwa tindakan kesehatan yang tersedia akan mencegah suatu penyakit (Glanz,2002). 


\section{KESIMPULAN}

Sebagain besar tingkat pengetahuan gizi ibu pada anak autis di Kota Bengkulu memiliki tingkat pengetahuan yang tinggi. Tidak ada hubungan antara pengetahuan gizi dengan kepatuhan Ibu pada anak autis

\section{DAFTAR RUJUKAN}

Arikunto, Suharsimi, 2006. Prosedur Penelitian: Suatu Pendekatan Praktek, Edisi Revisi, PT. Rineka Cipta. Jakarta.

Centre for Disease Control and Prevention. Morbity and Mortality Weekly Report:Prevalence of Autisme Spectrum Disorders- Autsim and Developmental Disablities Monitoring Network, 14 sites, United states, 2008. United States : Office Surveillance, Epidemiology, and Laboratory Services, Centers. (Homepage on the internet. 2015. Dikutip pada tanggal 07 November 2015 (22:32) Diunduh dari http://www.cdc.gov/mmwr/pdf/ss/ss6103.pd f.

Dewanti, 2014. Pengaruh Diet Bebas Gluten dan Kasein terhadap Perkembangan Anak Autis di SLB Khusus Autistik Fajar Nugraha Sleman. Yogyakarta. Diakses pada tanggal 13 Oktober 2015

Fadhli, A. 2010. Buku Pintar Kesehatan Anak. Pustaka Anggrek. Yogyakarta

Farlina, Heni. 2015. Artikel. Faktor-faktor yang Berhubungan dengan Kepatuhan Orang Tua dalam Menerapkan Diet Bebas Gluten dan bebas casein pada anak autis Di yayasan Autis Mitra Ananda Padang Tahun 2015. Padang 2015.

Glanz, Karen, 2002. Health Behavior and Health Education. San fransisco: Jossey-Bass.

Hendrawati, Hermano Edi. 2010. Jurnal Hubungan tingkat pengetahuan orang tua dengan pemberian Diet casein Free dan Gluten free $(C F G F)$ : Padang Panjang

Kidd, L.S. 2013. Anakku Autis Aku Harus Bagaimana?. Jakarta: PT Bhuana Ilmu Populer Kelompok Gramedia

Koka, E.M. 2011. Perilaku Ibu tentang Pemberian Makan dan Status Gizi Anak Autism di Kota Binjai Tahun 2011. Di unduh http://repository.usu.ac.id.

Kusumayanti. 2005. Hubungan antara Konsumsi Casein, Gluten dan Pola Aktifitas yang Khas pada Anak Penyandang Autis di Denpasar. Jurnal Perilaku Ibu Dan Konsumsi Jenis Makanan Sumber Gluten Dan Kasein Pada di Kota Bengkulu tahun 2016. Diharapkan bagi orang tua untuk tetap memperhatikan kecukupan gizi pada responden dan pantangan yaitu sumber makanan dari gluten dan kasein.

Anak Autis Di Yayasan Putra Putri Cerdas Mandiri, Ciputat,.Tangerang Selatan 2012.

Mashabi. NA., dan Tajjudin. NR. 2009. Hubungan antara Pengetahuan Gizi Ibu dengan Pola Makan Anak Autis. Tata Boga Ilmu Kesejahteraan Keluarga, Fakultas Teknik, Universitas Negeri Jakarta, Jakarta. https://kuliahfery.files.wordpress.com/2010/ o6/autisme.pdf.10 Oktober 2015 (08.25)

Notoatmodjo, Soekidjo. 2003. Metodologi Penelitian. Jakarta: Rineka Cipta.

Notoatmodjo, S. 2010. Metodologi Penelitian Kesehatan. Jakarta: PT Asdi Mahasatya.

Priyatna, Andri. 2010. Amazing Autisme: Memahami, Mengasuh, dan Mendidik Anak Autis. Jakarta: PT Elex Media Komputindo

Puspita, D. 2004. Makalah : Masalah peran keluarga pada penanganan individu autistic spectrum disorder. Jakarta : Yayasan Autisma Indonesia Sastra

Gusdi. 2011. Neurolinguistik Suatu Pengantar.Jurnal Hubungan Kepatuhan Orang Tua Menerapkan Diet Bebas Gluten dan Kasein (GFCF) dengan Perilaku Anak Autis di Yayasan Autis Center "CAKRA” Pucang Jajar Surabaya.2014. 10 Oktober 2015 (08.27)

Sastry, A., dan Aguirre. B. 2012. Parenting Anak dengan Autisme. Yogyakarta: Pustaka Pelajar.

Soenardi, T., dan Soetardjo, S. 2007. Terapi Makanan Anak dengan Gangguan Autisme. Jakarta: PT Penerbitan Sarana Bobo.

Sunu, Christopher. 2012. Panduan Memecahkan Masalah Autisme: Unlocking Autism. Sleman Yogyakarta : Lintang Terbit.

Veskarisyanti, Galih A. 2008. 12 Terapi Autis Paling Efektif \& Hemat untuk Autisme, Hiperaktif, dan Retardasi Mental. Yogyakarta : Pustaka Anggrek

Winarno, F.G., Agustinah, W, dan Sanyoto, R. 2009. Panduan Praktis Pemberian Makanan Sehat, Lezat, dan Tepat Bagi Anak dengan Autis. Jakarta: PT. Gramedia Pustaka Utama.

Winarno. 2013. Autisme Dan Peran Pangan. Jakarta : PT. Gramedia Pustaka Utama. 